\title{
Resistensi Beberapa Varietas Bawang Merah Terhadap Colletotrichum Gloeosporioides
}

\author{
Hekmawati $^{1)}$, Susilo Hambeg Poromarto ${ }^{2)}$, Salim Widono ${ }^{2)}$
}

\begin{abstract}
Shallot is an important vegetable because it is needed for seasoning and beneficial for health. One of the problems in shallot cultivation is the decrease in productivity due to Colletotrichum gloeosporioides attack that caused anthracnose disease. The use of resistant varieties is a solution to control C. gloeosporioides which is safe and doesn't cause environmental damage. Shallot consists of many varieties, but their resistance level remains unknown. The research aimed to test the resistance of some varieties of shallots to $C$. gloeosporioides. Shallots varieties tested are Tajuk, Bauji, Bima Curut, Bima Rajat, Bali Lancur and Bali Karet. The research used a onefactor completely randomized design with 12 treatments and 5 replications. The results of the research showed that Tajuk, Bima Curut, Bali Lancur and Bali Karet varieties were highly susceptible due to disease severity of more than $71 \%$, have a faster incubation period of anthracnose, high disease incidence and a significant decrease in tuber. Bauji and Bima Rajat varieties are classified as susceptible varieties due to disease severity of $64 \%$ but have a longer incubation period of anthracnose, higher number of tubers, higher fresh and dry weight of tubers and lower reduction in the number and weight of tubers.
\end{abstract}

Keywords: Anthracnose, Susceptible Variety, Disease Severity

\section{PENDAHULUAN}

Bawang merah (Allium cepa var. Ascalonicum) merupakan komoditas sayuran penting karena banyak dibutuhkan untuk bumbu masakan, serta kandungan biokimianya seperti antioksidan dan quercetin bermanfaat untuk kesehatan (Roldan et al. 2008). Kandungan bakterisid pada bawang merah bermanfaat sebagai obat luka (Misna dan Diana 2016). Bawang merah juga bermanfaat menurunkan kolesterol dan kadar gula darah terutama pada penderita diabetes militus (Ozougwu dan Jevas 2011).

Produksi bawang merah di Indonesia pada tahun 2014 mencapai 1.233 .984 ton, namun pada tahun 2015 mengalami penurunan sebesar $0,39 \%$ menjadi 1.229.184 ton (BPS 2015). Penurunan produktivitas dan kualitas bawang merah menurut sebagian besar petani (87-90\%) disebabkan oleh masalah kerusakan tanaman akibat penyakit, kabut, hama, dan hujan (Basuki 2014). Salah satu penyakit utama bawang merah yaitu antraknosa yang disebabkan oleh Colletotrichum gloeosporioides (Nova et al. 2011). Serangan C. gloeosporioides dapat menyebabkan kerusakan hingga $100 \%$ dan mengurangi kandungan gula serta protein pada bawang merah (Alberto 2014).

Penggunaan fungisida efektif untuk mengendalikan patogen namun residu yang ditinggalkan menyebabkan kerusakan lingkungan (Aktar et al. 2009). Salah satu cara pengendalian C. gloeosporioides sesuai sistem

1) Mahasiswa Program Studi Agroteknologi Fakultas Pertanian UNS, Surakarta

2) Staf Pengajar Program Studi Agroteknologi Fakultas Pertanian UNS, Surakarta

Author Contact: hekma226@gmail.com pertanian berkelanjutan yaitu dengan menggunakan varietas resisten (Kirana et al. 2014). Pengujian resistensi varietas bawang merah belum banyak dilakukan di Indonesia, oleh karena itu dalam penelitian ini akan dilakukan pengujian resistensi beberapa varietas bawang merah terhadap C. gloeosporioides penyebab antraknosa.

\section{METODE PENELITIAN}

Penelitian dilaksanakan di Laboratorium Hama dan Penyakit Tumbuhan Universitas Sebelas Maret Surakarta dan Rumah Kaca Laboratorium Penelitian Hama dan Penyakit Tanaman Palur pada bulan Oktober 2017 sampai Juni 2018. Bahan yang digunakan yaitu polybag dan media tanam, benih bawang merah varietas Tajuk, Bauji, Bima Curut, Bima Rajat, Bali Lancur dan Bali Karet serta C. gloeosporioides. Alat yang digunakan yaitu autoklaf, LAF (Laminar Air Flow), mikroskop binokuler dan handsprayer. Penelitian menggunakan Rancangan Acak Lengkap (RAL) satu faktor dengan 12 perlakuan dan 5 kali ulangan. Setiap ulangan terdiri dari 4 tanaman bawang merah sebagai sampel sehingga terdapat 240 unit sampel yang terdiri dari 120 sampel dengan inokulasi C. gloeosporioides dan 120 sampel tanpa inokulasi.

Pelaksanaan penelitian dimulai dari isolasi C. gloeosporioides dari daun bawang merah yang menunjukkan gejala penyakit antraknosa. Kultur spora tunggal berfungsi untuk mendapatkan isolat murni C. gloeosporioides. Uji patogenesitas dilakukan pada buah apel dan tanaman bawang merah. Penanaman bawang merah menggunakan teknik microcutting dan setiap polybag ditanami 4 umbi. Uji resistensi beberapa varietas bawang merah terhadap $C$. gloeosporioides dilakukan dengan menyemprotkan suspensi 
C. gloeosporioides sebanyak 4,8 $\mathrm{ml}$ dengan kerapatan $2,5 \times 10^{6} \mathrm{spora} / \mathrm{ml}$ pada daun bawang merah yang berumur 5 MST kemudian tanaman bawang merah disungkup dengan plastik selama 2 hari. Tanaman yang tidak diinokulasi patogen disemprot aquades steril dengan volume yang sama. Pemanenan varietas Tajuk, Bauji, Bima Curut dan Bima Rajat dilakukan ketika umur 65 hari, sedangkan varietas Bali Lancur dan Bali Karet dipanen ketika umur 80 hari. Variabel pengamatan untuk mengetahui tingkat resistensi meliputi keparahan penyakit, masa inkubasi dan insidens penyakit. Pengamatan dilakukan 3 hari sekali sejak inokulasi sampai panen. Penentuan keparahan penyakit dilakukan berdasarkan nilai skor kerusakan tanaman.

Tabel 1 Pengelompokan skor kerusakan tanaman bawang merah akibat penyakit antaknosa menurut Patil (2013)

\begin{tabular}{|c|c|c|}
\hline Skor & $\begin{array}{c}\text { Persentase } \\
\text { Kerusakan (\%) }\end{array}$ & Keterangan \\
\hline 0 & 0 & Tidak ada gejala \\
\hline 1 & $1-10 \%$ & $\begin{array}{l}\text { Daun terdapat bercak putih } \\
\text { berbentuk oval, daun keriting } \\
\text { dan klorosis }\end{array}$ \\
\hline 2 & $11-20 \%$ & $\begin{array}{l}\text { Pemanjangan daun dan } \\
\text { batang semu tidak normal, } \\
\text { aservuli muncul di } \\
\text { permukaan bercak }\end{array}$ \\
\hline 3 & $21-40 \%$ & $\begin{array}{l}\text { Terdapat bintik-bintik } \\
\text { nekrotik yang dangkal dan } \\
\text { cekung pada bercak dengan } \\
\text { aservuli }\end{array}$ \\
\hline 4 & $41-60 \%$ & $\begin{array}{llr}\text { Batang semu memanjang, } & \text { mecil dan daun } \\
\text { umbi ke } & \text { dan } \\
\text { menunjukkan gejala mati } \\
\text { pucuk }\end{array}$ \\
\hline 5 & $>61 \%$ & $\begin{array}{l}\text { Mati pucuk berat, umbi } \\
\text { membusuk, perubahan } \\
\text { warna akar }\end{array}$ \\
\hline
\end{tabular}

Keparahan penyakit antraknosa dihitung dengan menggunakan rumus: $\quad K p=\frac{\sum(n i \times v i)}{Z \times N} \times 100 \%$
$\mathrm{Kp} \quad$ : keparahan penyakit (\%)
$\mathrm{n}_{\mathrm{i}} \quad$ : jumlah tanaman yang terserang
$\mathrm{v}_{\mathrm{i}} \quad$ : nilai kategori dari tanaman terserang
$\mathrm{N} \quad$ : nilai kategori tertinggi
Z : jumlah seluruh tanaman yang diamati

Tabel 2 Kriteria resistensi tanaman bawang merah terhadap penyakit antraknosa didasarkan pada keparahan penyakit menurut Syukur et al. (2011)

\begin{tabular}{ccl}
\hline No. & Keparahan Penyakit (\%) & \multicolumn{1}{c}{ Kategori } \\
\hline 1 & $0-10$ & Sangat Resisten \\
2 & $11-20$ & Resisten \\
3 & $21-40$ & Agak Resisten \\
4 & $41-70$ & Rentan \\
5 & $71-100$ & Sangat Rentan \\
\hline
\end{tabular}

Variable pengamatan pasca panen yaitu jumlah umbi, bobot umbi segar dan bobot umbi kering. Data yang diperoleh dianalisis menggunakan uji $F$ jika berpengaruh nyata diuji dengan DMRT 5\%.

\section{HASIL DAN PEMBAHASAN}

\section{Resistensi Varietas Bawang Merah}

Varietas bawang merah yang terdiri dari varietas Tajuk, Bauji, Bima Curut, Bima Rajat, Bali Lancur dan Bali Karet tidak menunjukkan adanya varietas yang resisten terhadap C. gloeosporioides penyebab antraknosa. Semua varietas bawang merah menunjukkan gejala antraknosa dengan tingkat keparahan dan insidens penyakit yang tinggi (Tabel 3) serta adanya penurunan hasil umbi bawang merah. Menurut Turaidar et al. (2018) varietas resisten menunjukkan gejala penyakit dengan tingkat keparahan yang rendah seperti munculnya bercak dalam jumlah dan ukuran yang sangat kecil.

Tabel 3 Perkembangan penyakit antraknosa pada beberapa varietas bawang merah

\begin{tabular}{lrrrl}
\hline \multicolumn{1}{c}{ Varietas } & $\begin{array}{c}\text { Masa inkubasi } \\
\text { (hari) }\end{array}$ & $\begin{array}{c}\text { Insidens Penyakit } \\
(\%)\end{array}$ & $\begin{array}{c}\text { Keparahan } \\
\text { Penyakit (\%) }\end{array}$ & Kategori \\
\hline Tajuk (tanpa Inokulasi) & $\mathrm{NA}$ & $0 \pm 0 \mathrm{a}$ & $0 \pm 0 \mathrm{a}$ & - \\
Tajuk (inokulasi) & $7 \pm 2 \mathrm{bc}$ & $100 \pm 0 \mathrm{c}$ & $95 \pm 11 \mathrm{c}$ & Sangat Rentan \\
Bauji (tanpa Inokulasi) & $\mathrm{NA}$ & $0 \pm 0 \mathrm{a}$ & $0 \pm 0 \mathrm{a}$ & - \\
Bauji (inokulasi) & $8 \pm 1 \mathrm{c}$ & $100 \pm 0 \mathrm{c}$ & $64 \pm 11 \mathrm{~b}$ & Rentan \\
Bima Curut (tanpa Inokulasi) & $\mathrm{NA}$ & $0 \pm 0 \mathrm{a}$ & $0 \pm 0 \mathrm{a}$ & - \\
Bima Curut (inokulasi) & $8 \pm 3 \mathrm{c}$ & $100 \pm 0 \mathrm{c}$ & $92 \pm 15 \mathrm{c}$ & Sangat Rentan \\
Bima Rajat (tanpa Inokulasi) & $\mathrm{NA}$ & $0 \pm 0 \mathrm{a}$ & $0 \pm 0 \mathrm{a}$ & - \\
Bima Rajat (inokulasi) & $10 \pm 5 \mathrm{~d}$ & $100 \pm 0 \mathrm{c}$ & $64 \pm 18 \mathrm{~b}$ & Rentan \\
Bali Lancur (tanpa Inokulasi) & $\mathrm{NA}$ & $0 \pm 0 \mathrm{a}$ & $0 \pm 0 \mathrm{a}$ & - \\
Bali Lancur (inokulasi) & $5 \pm 1 \mathrm{~b}$ & $100 \pm 0 \mathrm{c}$ & $94 \pm 8 \mathrm{c}$ & Sangat Rentan \\
Bali Karet (tanpa Inokulasi) & $7 \pm 4 \mathrm{bc}$ & $10 \pm 14 \mathrm{~b}$ & $2 \pm 3 \mathrm{a}$ & - \\
Bali Karet (inokulasi) & $5 \pm 1 \mathrm{~b}$ & $100 \pm 0 \mathrm{c}$ & $94 \pm 6 \mathrm{c}$ & Sangat Rentan \\
\hline
\end{tabular}

Keterangan: Angka pada kolom sama yang diikuti huruf sama tidak berbeda nyata pada uji jarak berganda Duncan $(P<0,05), \mathrm{NA}=$ tidak muncul gejala antraknosa

Varietas Bauji dan Bima Rajat menunjukkan keparahan penyakit $64 \%$ dan varietas Tajuk, Bima
Curut, Bali Lancur serta Bali Karet menunjukkan keparahan penyakit antraknosa lebih dari 90\% (Tabel 
3). Berdasarkan Syukur et al. (2011) Bauji dan Bima Rajat tergolong varietas rentan sedangkan empat varietas lainnya tergolong varietas sangat rentan (Tabel 3). Maheshwari et al. (2015) menyatakan varietas yang sangat rentan menampakkan gejala penyakit dengan keparahan yang lebih tinggi dibanding varietas rentan. Semakin tinggi keparahan penyakit maka semakin rentan suatu varietas terhadap serangan patogen.

Semua varietas bawang merah yang diuji diduga mempunyai lapisan epidermis daun yang tipis karena daun bawang merah bertekstur lunak dan lentur. Hal tersebut mempermudah C. gloeosporioides menginfeksi jaringan daun bawang merah sehingga keparahan penyakit antraknosa tinggi. Marlitasari et al. (2016) menyatakan bahwa lapisan epidermis yang tebal dan kuat akan menghambat penetrasi langsung oleh patogen.

Semua varietas bawang merah menunjukkan insidens penyakit (IP) mencapai $100 \%$ artinya semua tanaman bawang merah terinfeksi $C$. gloeosporioides (Tabel 3). Ratulangi et al. (2012) menyatakan varietas rentan dan kondisi lingkungan yang sesuai bagi perkembangan patogen $C$. gloeosporioides dapat menimbulkan insidens penyakit tinggi dan kerusakan yang serius. Menurut Palupi et al. (2015) semakin besar insidens penyakit maka semakin rentan suatu galur terhadap suatu penyakit dan sebaliknya.

Varietas sangat rentan dengan keparahan penyakit tinggi memiliki masa inkubasi antraknosa yang lebih cepat dibanding varietas rentan dengan keparahan penyakit yang lebih rendah (Tabel 3). Hal tersebut sesuai dengan pernyataan Marlitasari et al. (2016), masa inkubasi berhubungan dengan keparahan penyakit. Semakin lama masa inkubasi patogen maka semakin rendah keparahan penyakitnya dan sebaliknya semakin cepat masa inkubasi patogen maka keparahan penyakit yang ditimbulkan semakin besar.

Varietas Bima Rajat memiliki masa inkubasi antraknosa yang paling lama dibanding varietas lainnya. Hal ini diduga karena varietas Bima Rajat mempunyai ketahanan struktural berupa struktur daun yang mampu menghambat penetrasi $C$. gloeosporioides ke dalam tanaman. Purwantisari et al. (2016) menyatakan tanaman yang mempunyai ketahanan struktural akan membuat patogen memerlukan waktu yang lebih lama untuk menginfeksinya dengan kata lain masa inkubasi lebih lama.

Varietas Tajuk mempunyai masa inkubasi antraknosa yang relatif cepat dan keparahan penyakit tertinggi (Tabel 3). Varietas Tajuk mampu membentuk daun yang cukup banyak (Tabel 4). Daun yang rimbun akan meningkatan kelembaban di sekitar pertanamam sehingga mendukung untuk perkembangan C. gloeosporioides. Hal tersebut sesuai dengan pendapat Colletti dan Lourenco (2014) yang menyatakan bahwa $C$. gloeosporioides akan lebih cepat menginfeksi tanaman pada suhu rendah $\left(15^{\circ} \mathrm{C}\right)$, kelembaban tinggi dan tanaman tersebut rentan terhadap patogen. Kondisi lingkungan yang sesuai untuk perkembangan patogen menyebabkan masa inkubasi lebih pendek atau cepat.

\section{Penurunan Umbi Bawang Merah}

Tanaman bawang merah yang diinokulasi C. gloeosporioides menghasilkan jumlah umbi, bobot umbi segar dan bobot umbi kering yang lebih rendah (Tabel 4) serta umbi yang lebih kecil dan pipih (panjang) dibanding tanaman yang tidak diinokulasi (Gambar 1). Infeksi C. gloeosporioides menyebabkan kerusakan daun seperti adanya bercak, klorosis, nekrosis dan pertumbuhan abnormal sehingga persentase daun sehat rendah. Hal tersebut menyebabkan proses fotosintesis yang tidak optimal dan berdampak pada terhambatnya proses pembentukan dan pematangan umbi serta menurunkan kualitas umbi karena umbi berukuran kecil (Gambar 1) dan tidak keras sehingga menurunkan bobot umbi. Hasil tersebut didukung oleh Carretero et al. (2011) bahwa serangan patogen pada daun menyebabkan berkurangnya luas daun hijau dan jumlah klorofil sehingga penyerapan cahaya matahari dan $\mathrm{CO}_{2}$ rendah. Siliquini et al. (2015) menyatakan rendahnya luas daun hijau menyebabkan laju fotosintesis rendah sehingga menghasilkan umbi bawang merah dengan bobot rendah pula.

Tabel 4 Pengaruh C. gloeosporioides terhadap hasil umbi beberapa varietas bawang merah

\begin{tabular}{lccc}
\hline \multicolumn{1}{c}{ Varietas } & Jumlah umbi & Bobot umbi segar $(\mathrm{g})$ & Bobot umbi kering $(\mathrm{g})$ \\
\hline Tajuk (tanpa Inokulasi) & $8 \pm 1 \mathrm{f}$ & $11,4 \pm 5 \mathrm{de}$ & $9,2 \pm 4,5 \mathrm{de}$ \\
Tajuk (inokulasi) & $1 \pm 1 \mathrm{a}$ & $1,1 \pm 1,7 \mathrm{ab}$ & $0,8 \pm 1,4 \mathrm{ab}$ \\
Bauji (tanpa Inokulasi) & $6 \pm 1 \mathrm{de}$ & $13,9 \pm 4,6 \mathrm{e}$ & $11,5 \pm 4,5 \mathrm{e}$ \\
Bauji (inokulasi) & $5 \pm 2 \mathrm{~cd}$ & $6,1 \pm 3,1 \mathrm{c}$ & $4,1 \pm 2,9 \mathrm{bc}$ \\
Bima Curut (tanpa Inokulasi) & $6 \pm 2 \mathrm{e}$ & $8,4 \pm 4,8 \mathrm{~cd}$ & $6,4 \pm 4,6 \mathrm{~cd}$ \\
Bima Curut (inokulasi) & $1 \pm 1 \mathrm{a}$ & $0,4 \pm 0,6 \mathrm{a}$ & $0,1 \pm 0,2 \mathrm{ab}$ \\
Bima Rajat (tanpa Inokulasi) & $5 \pm 0 \mathrm{de}$ & $12,0 \pm 3,5 \mathrm{de}$ & $9,7 \pm 3,1 \mathrm{de}$ \\
Bima Rajat (inokulasi) & $4 \pm 1 \mathrm{bc}$ & $4,8 \pm 1,9 \mathrm{bc}$ & $2,6 \pm 1,5 \mathrm{abc}$ \\
Bali Lancur (tanpa Inokulasi) & $2 \pm 0 \mathrm{~b}$ & $5,0 \pm 1,8 \mathrm{bc}$ & $2,9 \pm 1,4 \mathrm{abc}$ \\
Bali Lancur (inokulasi) & $0 \pm \mathrm{a}$ & $0,0 \pm 0,0 \mathrm{a}$ & $0,0 \pm 0,0 \mathrm{ab}$ \\
Bali Karet (tanpa Inokulasi) & $3 \pm 1 \mathrm{~b}$ & $8,7 \pm 3,7 \mathrm{~cd}$ & $6,1 \pm 3,7 \mathrm{~cd}$ \\
Bali Karet (inokulasi) & $0 \pm 0 \mathrm{a}$ & $0,0 \pm 0,0 \mathrm{a}$ & $0,0 \pm 0,0 \mathrm{a}$ \\
\hline
\end{tabular}

Keterangan: Angka pada kolom sama yang diikuti huruf sama tidak berbeda nyata pada uji jarak berganda Duncan $(P<0,05)$ 


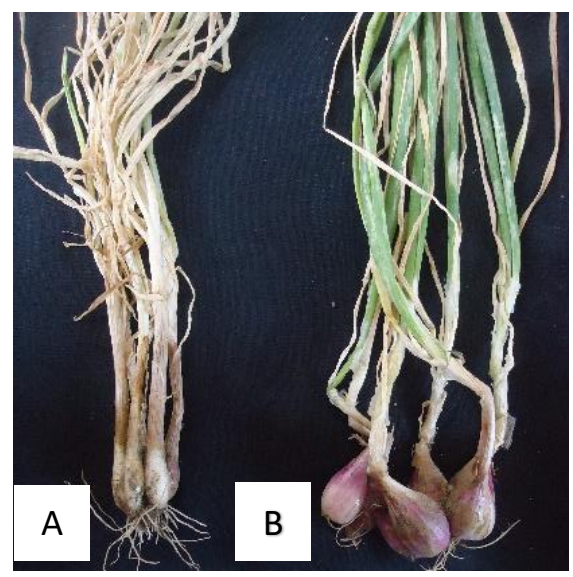

Gambar 1 Tanaman yang terinfeksi C. gloeosporioides menghasilkan umbi bawang merah yang lebih kecil dan panjang $(A)$ dibanding tanaman yang tidak terinfeksi $(B)$

Serangan C. gloeosporioides pada varietas Bali Lancur dan Bali Karet menyebabkan kehilangan umbi hingga $100 \%$ artinya tidak ada umbi yang dapat dipanen (Tabel 4). Kedua varietas tersebut tergolong sangat rentan, keparahan penyakit yang tinggi menyebabkan terhambatnya pembentukan umbi hingga kematian tanaman. Hasil tersebut selaras dengan Naguleswaran et al. (2014) bahwa serangan berat $C$. gloeosporioides menyebabkan umbi yang dihasilkan berukuran kecil dan akhirnya membusuk, akar tanaman menjadi kerdil hingga menyebabkan kematian tanaman.

Varietas Tajuk merupakan varietas yang mengalami penurunan jumlah umbi terbanyak yaitu 7 umbi per rumpun. Penurunan jumlah umbi terendah terjadi pada varietas Bauji dan Bima Rajat (Gambar 2). Hal tersebut dikarenakan kedua varietas mempunyai keparahan penyakit yang lebih rendah dibanding varietas lain (Tabel 3) sehingga penurunan jumlah umbi akibat penyakit antraknosa tidak terlalu besar. Menurut Suganda et al. (2016) kehilangan hasil akibat penyakit tergantung pada keparahan penyakit dan pengendalian yang dilakukan. Keparahan penyakit yang tinggi akan menurunkan hasil tanaman yang tinggi dan sebaliknya.

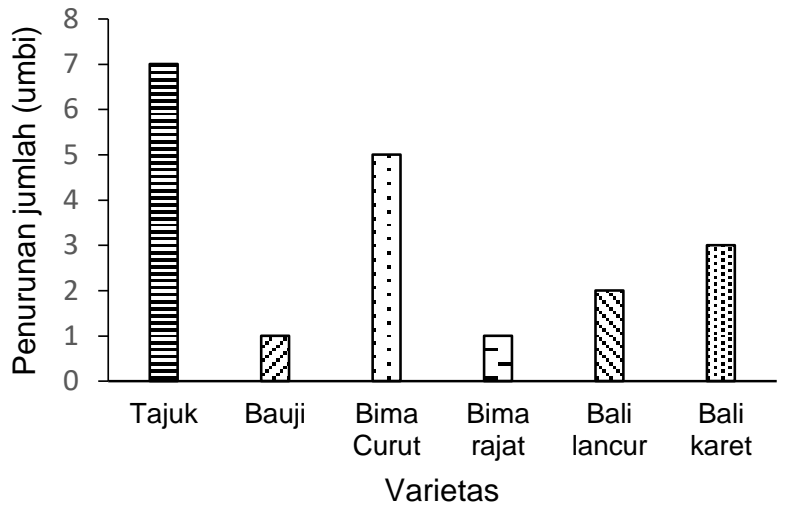

Gambar 2 Penurunan jumlah umbi bawang merah akibat $C$. gloeosporioides

Serangan C. gloeosporioides mampu menurunkan bobot umbi bawang merah semua varietas. Penurunan bobot umbi diduga karena serangan $C$. gloeosporioides mengurangi kandungan dalam bawang merah sehingga menyebabkan umbi tidak padat. Bawang merah yang terinfeksi patogen mempunyai kandungan protein, total gula (Ghangaonkar 2013), antioksidan dan vitamin C (Srivastava dan Kumar 2013) yang lebih rendah dibanding bawang merah sehat sehingga bobot umbi rendah.

Varietas Tajuk merupakan varietas yang mengalami penurunan bobot umbi segar dan bobot umbi kering terbanyak dibanding varietas lain. Hal tersebut dikarenakan adanya serangan $C$. gloeosporioides dengan keparahan penyakit 95\% (Tabel 3) dapat menurunkan bobot umbi segar hingga $10,3 \mathrm{~g}$ dan bobot umbi kering hingga $8,4 \mathrm{~g}$ per rumpun (Gambar 5). Varietas Bima Rajat mengalami penurunan bobot umbi segar yang paling kecil dari keempat varietas yang dipanen. Serangan $C$. gloeosporioides dengan keparahan penyakit 64\% (Tabel 3) menyebabkan penurunan bobot umbi segar dan umbi kering 7,1 g (Gambar 3).

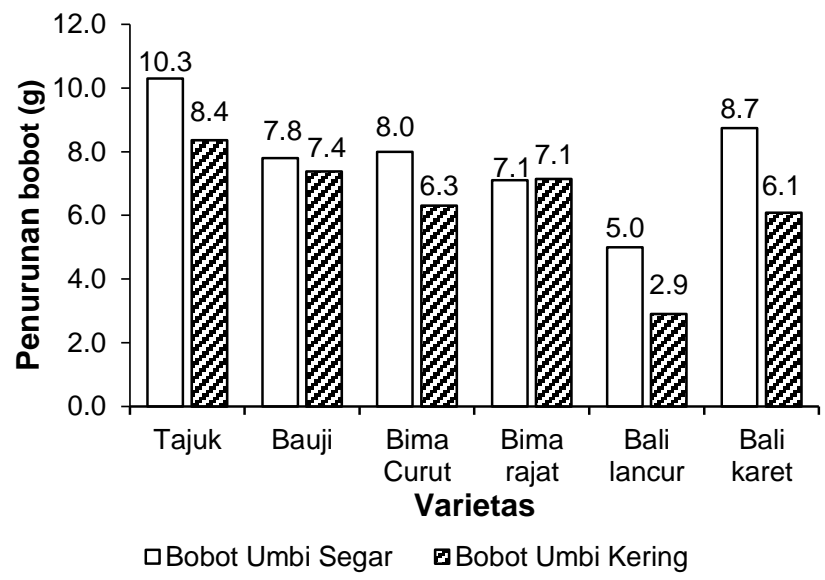

Gambar 3 Penurunan bobot umbi segar dan bobot umbi kering akibat $C$. gloeosporioides

\section{KESIMPULAN}

Berdasarkan penelitian yang telah dilaksanakan, maka dapat diambil kesimpulan sebagai berikut:

1. Semua varietas bawang merah yang diuji memiliki resistensi yang rendah terhadap Colletotrichum gloeosporioides penyebab penyakit antraknosa.

2. Varietas Tajuk, Bima Curut, Bali Lancur dan Bali Karet tergolong varietas yang sangat rentan karena keparahan penyakit lebih dari $90 \%$.

3. Varietas Bauji dan Bima Rajat tergolong varietas rentan karena keparahan penyakit $64 \%$.

\section{DAFTAR PUSTAKA}

[BPS] Badan Pusat Statistik. 2015. Produksi bawang merah menurut provinsi 2011-2015. Badan pusat statistik Indonsia . Jakarta.

Aktar MW, Sengupta D, Chowdhury A. 2009. Impact of pesticides use in agriculture: their benefits and hazards. J Interdisc Taxicol 2(1): 1-12. DOI: 10. 2478/v10102-009-0001-7.

Alberto RT. 2014. Pathological response and biochemical changes in Allium cepa L. (bulb onions) infected with anthracnose-twister disease. 
$J$ Plant Pathol Quar 4(3): 23-31. DOI: $10.5943 / \mathrm{ppq} / 4 / 1 / 4$.

Basuki RS. 2014. Identifikasi permasalahan dan analisis usahatani bawang merah di Dataran Tinggi Pada Musim Hujan di Kabupaten Majalengka. J Hort 24(3): 266-275.

Carretero R, Bancal MO, Miralles DJ. 2011. Effect of leaf rust (Puccinia triticina) on photosynthesis and related processes of leaves in wheat crops grown at two contrasting sites and with different nitrogen levels. Europ. J Agron 35: 237-246. DOI: 10.1016/j.eja.2011.06.007.

Colletti ARS, Lourenco SA. 2014. Effect of temperature, wetness duration and cultivar on the development of anthracnose in guava fruits. J Summa Phytopathol 40(4): 307-312.

Ghangaonkar NM. 2013. Studies on biochemical changes in infected onion bulbs. J Sci 2(1): 7-8.

Kirana R, Kusmana, Hasyim A, Sutarya R. 2014. Persilangan cabai merah tahan penyakit antraknosa (Colletotrichum acutatum). J Hort 24(3): 189-195.

Maheshwari SK, Choudhary BR, Singh D, Sharma BD, Sharmia SK. 2015. Evaluation of resistance in different varieties/genotypes of bottle gourd (Lagenaria siceraria) against Cercospora leaf spot under field conditions. Indian J of Agr Sci 85(10): 21-24.

Marlitasari E, Sulistyowati L, Kusuma RR. 2016. Hubungan ketebalan lapisan epidermis daun terhadap infeksi jamur Alternaria porri penyebab penyakit bercak ungu pada empat varietas bawang merah. J HPT 4(1): 8-16.

Misna, Diana K. 2016. Aktivitas antibakteri ekstrak kulit bawang merah (Allium cepa I.) terhadap bakteri Staphylococcus aureus. J Ganelika Pharm 2(2): 138-144.

Naguleswaran V, Pakeerathan K, Mikunthan G. 2014. Biological control: a promising tool for bulb-rot and leaf twisting fungal diseases in red onion (Allium cepa L.) in Jaffna District. J World Appl Sci J 31(6): 1090-1095.

DOI: 10.5829/idosi.wasj.2014.31.06.292.

Nova MXV, Borges LR, Sousa ACB, Brasileiro BTRV, Lima EALA et al. 2011. Pathogenicity for onion and genetic diversity of isolates of the pathogenic fungus Colletotrichum gloeosporioides (Phyllachoraceae) from the State of Pernambuco, Brazil. J Genet Mol Res 10(1): 311-320.
Ozougwu, Jevas C. 2011. Anti-diabetic effects of Allium cepa (onions) aqueous extracts on alloxan-induced diabetic Rattus novergicus. J of Med Plants Res 5(7): 1134-1139.

Palupi H, Yulianah I, Respatijarti. 2015. Uji ketahanan 14 galur cabai besar (Capsicum annuum L.) terhadap penyakit antraknosa (Colletotrichum spp) dan layu bakteri (Ralstonia solanacearum). J Produksi Tanaman 3(8): 640-648.

Patil S. 2013. Onion twister disease : etiology, their characterization, epidemiology and integrated management. Dharward (IN): University of Agricultural Sciences.

Purwantisari S, Priyatmojo A, Sancaningsih RP, Kasiamdari RS. 2016. Masa inkubasi gejala penyakit hawar daun tanaman kentang yang diinduksi ketahanannya oleh jamur antagonis Trichoderma viride. J Bioma 18(1): 41-47. DOI: 10.1470/bioma.

Ratulangi MM, Sembel DT, Rante CS, Dien MF, Meray ERM. 2012. Diagnosis dan insidensi penyakit antraknosa pada beberapa varietas tanaman cabe di Kota Bitung dan Kabupaten Minahasa. J Eugenia 18(2): 81-90.

Roldan E, Moreno CS, Ancos B, Cano MP. 2008. Characterisation of onion (Allium cepa L.) byproducts as food ingredients with antioxidant and antibrowning properties. J Food Chem 108: 907916. DOI: 10.1016/j.foodchem.2007.11.058.

Siliquini OA, Orioli GA, Lobartini JC. 2015. Onion yield as affected by plant density, nitrogen level and loss of leaf area. J Intern Exp Bot 84: 338-344.

Srivastava A, Kumar S. 2013. Biochemical Changes in post harvested Allium cepa (Onion) and Capsicum annuum (Capsicum) under the influence of pathogens. J AVS 5(4): 18-21.

Suganda T, Yulia E, Widiantini F, Hersanti. 2016. Intensitas Penyakit Blas (Pyricularia oryzae Cav.) pada padi varietas ciherang di lokasi endemik dan pengaruhnya terhadap kehilangan hasil. J Agrikultura 27(3): 154-159.

Syukur M, Sujiprihati S, Koswara J, Widodo. 2009. Ketahanan terhadap antraknosa yang disebabkan oleh Colletotrichum acutatum pada Beberapa genotipe cabai (Capsicum annuum L.) dan korelasinya dengan kandungan kapsaicin dan peroksidase. J Agron Indonesia 37(3): 233-23.

Turaidar V, Reddy M, Anantapur R, Krupa KN, Dalawai $\mathrm{N}$ et al. 2018. Screening of traditional rice varieties (TRVs) for blast resistance. J Pharmacogn Phytochem 7(1): 1384-1388. 